Журба С. С.

кандидат філологічних наук, дочент

КПІ ДВНЗ «Криворізький начіональний університет»

\title{
ІНТЕРПРЕТАЦІЯ ПРОБЛЕМИ «ВТРАЧЕНОГО ПОКОЛІННЯ» У СВІТОВІЙ ТА УКРАЇНСЬКІЙ ЛІТЕРАТУРАХ
}

У статті порушено проблему «втраченого покоління» у творах світових та українських митців, присвячених подіям Першої світової та громадянської війни й повоєнної дійсності. У порівняльному аспекті звернено увагу на подібність світоглядів героїв украӥнських і німецького письменників, відчуття персонажами абсурдності буття і спроби подолання екзистенційного вакууму.

Ключові слова: «втрачене покоління», смисл буття, духовний світ, національне питання, психологізм.

В статье исследована проблема «потерянного поколения» в произведениях мировых и украинских писателей, посвященных событиям Первой мировой, гражданской войны и послевоенной действительности. В сравнительном аспекте обращено внимание на сходство мировоззрений героев украинских и немецкого писателей, ощущение персонажами абсурдности бытия и попытки преодоления экзистенциального вакуума.

Ключевые слова: «потерянное поколение», смысл бытия, духовный мир, национальный вопрос, психологизм.

The article deals with the problem of the "lost generation" in the international and Ukrainian artists' works devoted to the events of the First World War, The Civil 
War and post-war reality. In a comparative aspect the attention drawn to the similarity of heroes' worldviews created by Ukrainian and German writers, characters' feeling of the absurdity of the existence and attempts to overcome the existential vacuum.

Key words: "lost generation", the sence of life, the spiritual world, national issues, psychologism.

Політична криза у світі початку XX століття та національна боротьба в Україні не могли не залишити осторонь письменників того покоління, яке прагнуло показати злам особистості в складну добу руйнації цінностей, і яке пізніше назвуть «утраченим». Розв'язання проблеми сенсу буття людини, іiі духовного світу, духовного досвіду у взаємозв'язку зі світом взагалі було об'єктом творчих домагань митців, які, зосереджуючись на внутрішньому світі індивідуума, через свідомість, порухи душі, почуття передають складні людські взаємини на тлі суспільних зламів і катастроф.

Відтворення трагічної самотності людини у воєнний і післявоєнний період загалом набуло поширення у світовій та українській літературі: А. Барбюс - «Вогонь», Ф. Фіцджеральд - «По той бік раю», Е. М. Ремарк - «На Західному фронті без змін», «Повернення», «Три товариші»; Е. Хемінгуей - «Фієста» («І сходить сонце»), «Прощавай, зброє!»; Р. Олдінгтон - «Смерть героя», Ю. Яновський - «Чотири шаблі», Б. Лепкий - «Зірка» та інші. Усі ці твори про «втрачене покоління», яке в післявоєнні роки шукає своє місце в суспільстві. Проблема національної ідеї та ії знищення порушена Б. Лепким у повісті «Зірка». Як і Б. Лепкий, Ю. Яновський у романі «Чотири шаблі» порушує складні проблеми духовного буття людини, питання, пов'язані з історичною долею українського народу. Вітчизняні митці апелюють до національного питання, натомість європейські письменники, звертаючись до проблеми «втраченого покоління», наголошують на втраті душевної рівноваги, на «загубленості» в новому житті.

До проблеми «втраченого покоління» в сучасному вітчизняному літературознавстві принагідно зверталися В. Агеєва, О. Кордонець, В. Панченко, Р. Харчук. Прочитання цієї проблеми в повісті «Зірка» Б. Лепкого, романах «Чотири шаблі» Ю. Яновського, 
«На Західному фронті без змін», «Три товариші» Е. М. Ремарка дає можливість у порівняльному аспекті співвіднести поетику і типологію художніх творів про людей світової війни, простежити інтертекстуальні зв'язки текстів, визначити місце у світовому літературному контексті.

Означник «утрачене покоління» належить американській письменниці Гертруді Стайн. Уперше цей вислів ужив як епіграф до роману «Фієста» («І сходить сонце») Ернест Хемінгуей. До цієї проблеми у світовій літературі зверталися у творах, написаних майже одночасно і виданих у 1929 році, Еріх Марія Ремарк, Ернест Хемінгуей, Ричард Олдінгтон. Харківське видавництво «Рух» оприлюднило в 1930 році переклад повісті Е. М. Ремарка «На Західному фронті без змін». Твори цих митців, як і роман Ю. Яновського та повість Б. Лепкого, були написані майже на десять років пізніше подій, зображених у них. Це було викликано суспільними та політичними процесами, зокрема економічною кризою в Свропі й світі 1929 року, тобто змінами, у яких людина війни не знаходить себе. На думку Сжи Коссака, «тягар світу і прив'язаність до нього, прив'язаність до межі і ницості, які оточують людину, метання між духовними ичінностями і потворністю матеріального середовища, породжують неперехідну втрату, усвідомлення трагедії долі» [Коссак 1980: 30].

Герої Ю. Яновського, учорашні активні учасники бойових дій, національного руху, «неймовірні герої, легендарні бійці Павлівки ци Успенівки» [Яновський 1983: 315], у мирних обставинах опиняються на обочині життя, стають «зайвими людьми» (В. Агеєва). На думку О. Петраша, однією з центральних проблем повісті «Зірка» Б. Лепкого є проблема «психічної реабілітації комбатантів національно-визвольної війни, їх пристосування до нових мирних умов, трудового влаштування» [Петраш 1993: 126].

Молодими юнаками герої Е. М. Ремарка пішли на фронт: «Війна вирвала нас із трунту. Для інших, старших, війна - це тільки якийсь часовий відтинок, вони можуть подумки його промину- 
ти. А нас війна вихопила із звичайного життя, і ми не знаємо, чим це скінчиться. ...Колись ми уявляли собі все це інакше. ...Ми не мали ніяких планів на майбутнє, думки про кар'єру $і$ професію тільки в небагатьох були практично вже визначені на все життя... Нас переконували, щчо натертий до блиску гудзик важливіиий, ніж чотири томи творів Шопенгауера. Попервах здивовані, далі пригнічені, й урешті збайдужілі, ми зрозуміли, що тут вирішальне значення має не душа, а щітка для взуття, не думка, а дисципліна, не воля, а муштра. Ми стали солдатами добровільно, пройняті ентузіазмом; але тут робили все, щзоб вибити у нас иче почуття» [Ремарк 1986: 44-45]. Юнаки розуміють, що ті цінності, які в мирний час вважалися домінуючими, на війні не мають значення. Муштра і дисципліна витісняють людське, і вага начищеного гудзика стає більшою за думки солдат. Пауль Боймер, осмислюючи суть війни і людини в ній, звіряється: «Я молодий, мені двадчять років, але в житті я бачив тільки відчай, смерть та поєднання безглуздої легковажності з неймовірними муками. Я бачу, щзо хтось нацьковує народ на народ, і люди вбивають -мовчки, слухняно, по-дурному, не розуміючи, щчо роблять, і не відчуваючи ніякої провини. Я бачу, щзо найкращі уми людства винаходять зброю і слова, аби це тривало й далі, та ще й у найвигадливіших формах. І разом зі мною иее бачать усі люди мого віку, ...зі мною иее переживає все моє покоління. ...Довгі роки ми робили тільки одне - убивали, ие стало нашою першою професією у житті. Все, що ми знаємо про життя, зводиться до одного - до смерті» [Ремарк 1986: 178].

Письменники змальовують складний стан людини, iii адаптацію після війни до нефронтового життя. Персонажі романів Е. М. Ремарка «На Західному фронті без змін» та «Три товариші», як і герої Б. Лепкого та Ю. Яновського, почуваються непотрібними в новому суспільстві. «Тепер ми повернемось втомлені, внутрішньо зруйновані, спустошені, усім чужі, позбавлені надій. Ми вже не зможемо знайти собі місия в житті. Та нас $i$ не зрозуміють, 
адже перед нами є старше покоління, яке, хоч і перебувало разом 3 нами на фронті, мало сім'ю і тепер знову займе своє місие в суспільстві $і$ забуде про війну, а за нами підростає покоління, яке нагадує нас, якими ми були раніше; і для нього ми будемо чужі, воно зімтовхне нас з дороги. Ми не потрібні самі собі, ми будемо жити і зістаремось - одні пристосуються, інші підкоряться долі, а багато не знайде собі місия. Пройдуть роки, і ми зійдемо зі сиени» [Ремарк 1986: 193], - заявляє Пауль Боймер, герой «На Західному фронті без змін». На його риторичні запитання «Що ж буде потім? І що буде з нами?» [Ремарк 1986: 178] автор дає відповіді у своїх наступних романах «Повернення», «Три товариші», герої яких разом намагаються вижити в складній повоєнній ситуації, морально підтримують один одного у важкі хвилини, допомагають забути страшні жахи війни і пристосуватись у новому для них суспільстві.

Адаптуватися до нових умов життя важко і персонажам Ю. Яновського: «Від молота кололо під серцем, рани свербіли, ніби не загоївшися. Поруйнувавши мирні дороги, вони самі їх мусили лагодити. Слава їхня швидко минула. Таки краще було б умерти в атащі, - не раз думали вони. Неймовірні герої, легендарні бійці Павлівки й Успенівки - Санька з Галатом поставали звичайними людьми. Їх забули, як забувають усе, щуо пережило свою славу. Вони били каміння на шосе $і$ давилися пилом з коліс» [Яновський 1983: 315]. Особливо болісним для них стає усвідомлення невідповідності вимріяного ідеалу і дійсності, мрії та реальності, заради яких вони ризикували життям. Яскравим підтвердженням є слова Галата: «Я розумію атаку і смерть, $і$ боротьбу, але я хочу відчути, щзо я є господар усього в країні» [Яновський 1983: 321]. Героя пригнічує відчуття знецінення ідеалів, заради яких він боровся, марність пролитої крові за краще майбутнє, яке залишило борців обабіч дороги: «Галат мріяв про ті щасливі години, коли він мчав на тачанці в атаку. Він бачив себе на поверхні землі, чув свою голосну i розбишацьку пісню. ...Та швидко Галат забув і мріяти. Треба було встигати вивозити до вагонеток вугілля» [Яновський 1983: 
323]. Реальність накладає відбиток на життя героїв, і ця несумісність несе зневіру, душевний злам, збільшується розрив між мрією й дійсністю. Смерть Марченка в цьому аспекті поглиблює трагічно-драматичне навантаження твору: «Його воля до життя погасла, як свічка... Він розквитався з землею як грач у карти, викинувши всі козирі $і$ заплативши програш. Тепер лежав він, простягшися на нарах - переможець життя. Його оточували друзі, невблаганно чекаючи останнього подиху» [Яновський 1983: 325].

Тема пристосування до нового життя розкривається й через образ головного героя повісті Б. Лепкого - Петра Пилипця. Колишній сотник Української Галицької Армії, що провів на війні десять років, опинився в таборі для інтернованих, звідки втік і потрапив на Закарпаття, Пилипець, підсумовуючи пережиті роки, говорить: «Касарня, стрілецькі рови, тиф і наскрізь передірявлена нога, так що можна туди инурок пересилити, як медведеві кільще через ніс» [Лепкий 1997: 489]. Утрата героєм смислу життя, який він убачав у служінні Українській Народній Республіці, приводить до нервових зрушень, неврівноваженості. Після завершення воєнних дій Пилипець не може відразу ж пристосуватись у суспільстві, й причиною цього є жахливі спогади про війну, нічні жахіття, звукові та зорові галюцинації.

Персонажі Е. М. Ремарка ще на війні розуміють свою зайвість у мирному житті, яке чекає їх попереду: «Можливо, ми зостанемось живі, але чи будемо насправді жити?» [Ремарк 1986: 101]. Очевидно, тому вони не бачать іншого виходу як самогубство і свідомо стають під кулі (Джордж Уінтерборн із роману Р. Олдінгтона «Смерть героя»), оскільки наперед розуміють свою непотрібність, відчувають спустошеність, марність життя, відчуження. Ю. Яновський також звертається до цієї теми: «Ми спустошені, Марченко, до краю спустошені для того, щзоб жити поодиниі... I тепер на порозі справжнього, увійшовщи в мужність, увесь час почуваємо на собі жах юності, свідомість непотрібності існуван- 
ня» [Яновський 1983: 309-310]. Проте герої Ю. Яновського бачать своє відродження в новій спільній мирній праці.

Віднайти смисл життя вдається і героєві Б. Лепкого - Петрові Пилипцю. Будучи музикантом за освітою, він стає диригентом оркестру в народному театрі. Відчуваючи своєю потрібність, насолоду від праці, герой прагне утвердження в житті. Змінюється смисл його життя й після знайомства з Марійкою, яку всі називають Зіркою. Взаємне кохання сотника 3 дівчиною наповнює його життя новим змістом, адже іiї ім'я є символом надії, певним дороговказом для зламаної душі героя. Петро Пилипець, який під час війни «втратив усе (навіть батьків) < ..> залишається в фабульно-сюжетній структурі повісті невлаштованим у матеріальному світі, але не одиноким і духовно не самотнім» [Дзись 2008: 8].

Для колишнього солдата-фронтовика, який намагається відшукати своє місце в післявоєнній Німеччині, Роберта Локампа 3 роману «Три товариші» Е. М. Ремарка своєрідним світлим променем стає Патриція Гольман. Кохання до цієї дівчини облагороджує героя, дає йому наснагу і наповнює смисл життя. Персонажів Б. Лепкого та Е. М. Ремарка поєднує не тільки погляд на життя, але й ненависть до війни. Роберт Локамп так підсумовує прожиті роки, зруйновані війною: «Ми хотіли вирушити в похід проти брехні, егойзму, жадоби й душевної інертності, бо все це змусило нас до того, щуо ми пережили. ...Але щуо з изього вийшло? Все стало брехнею, забулося. А хто не зміг забути, тому залишилися тільки безсилля, розпач, байдужість і горілка. Часи великих мрій, мрій людських і навіть суто чоловічих, канули в небуття» [Ремарк 1986: 204]. А сотник Петро Пилипець говорить: війна «відтручує, як погадати, скільки то людей погибло. I за щзо? Молодих, надійних людей» [Лепкий 1997: 493]. Герої Ремарка воювали за країну, що розпочала безглузду війну і зазнала поразки, а після закінчення кровопролиття поринула у вир революції, економічної кризи, безробіття й інфляції. Герої Б. Лепкого - «січові стрільці, учасники національно-визвольних змагань, які мали перед собою чітку мету 
- незалежність України. Письменник прагне показати, що після поразки збройної боротьби колишні фронтовики знаходять смисл свого життя у мирній праці. Саме тому у творі перемагає оптимізм, і повість "Зірка" закінчується щасливо», - указує О. Кордонець [Кордонець 208: 23].

Герої Ю. Яновського брали активну участь у боях громадянської війни. Персонажі Б. Лепкого, Е. М. Ремарка, Е. Хемінгуея, Р. Олдінгтона, А. Барбюса були учасниками Першої світової війни, тому історичний час у цих творах майже збігається. Перші розділи-пісні «Чотирьох шабель» пронизує дух героїчної романтики. Персонажів Е. М. Ремарка переповнюють «невиразні ідеї, щз надавали життю і навіть війні в наших очах ідеалізованого, майже романтичного сяйва» [Ремарк 1986: 45]. Війна не вбила в душах молодих людей почуття прекрасного, відчуття краси, прагнення жити: «Літо 1918 року... Ніколи ще наше життя в його нужденній подобі не здавалось нам таким бажаним, як тепер; червоні маки на луках біля казарм, лискучі кузки на стеблинах трав, теплі вечори в напівтемних прохолодних кімнатах, чорні, таємничі у сутінках дерева, зірки, дзюрчання води, мрї $i$ довгий сон... О життя, життя, життя» [Яновський 1983: 188]. Зображення громадянської війни в перших чотирьох новелах роману «Чотири шаблі» оповите романтикою: «Прекрасні хвилини! Ви ніколи не зітретесь $і$ не припадете пилом! Довго ще в тихих походах співатимуть вашу славу» [Яновський 1983: 248], в останніх - змінюється на «фікцію легенди» (М. Ласло-Куцюк), і герої мають змогу чути думу про себе, у якій показано все не так, як було насправді. Письменник, провіщуючи долю своїх героїв, указав, що «героїчна фаза історії зміниться чимось трагіко-жсорстоким» [Панченко 1994: 14]. Шахая «веде дорога вгору до мети. I, наближаючись до ясного верхів'я, він бачить нові й нові простори, оповиті туманамu» [Яновський 1983: 245]. Майбутнє, прекрасне і мрійливе, губиться в тумані. Може, тому у мирний час, працюючи на шахті i почувши пісню про свої подвиги, Шахай «подумав про селянство 
- двадиятип'ятимільйонну співочу силу. Про темне, невідоме й небезпечне море ї̈, про готовність без краю лити кров. Болючими йому здавалися минулі бої, криваві перемоги. Він відчув, щзо пече його наче жага, хтось викручує йому руки і ламає кості, трощить об колоду» [Яновський 1983: 317]. Остюк у снах влітає зі своєю кіннотою в Париж, проте переможене місто зустрічає його непривітно - «порожні вулиці, замкнені вікна і двері» [Яновський 1983: 284]. Майбутнє для героїв Ю. Яновського - це визнання їхньої слави, адже «слава тих, щуо загинуть, рятуючи справу й товаришів, вставатиме попереду нас, як осяяний прапор перемоги! Слава ия піде між народ по краӥні, $і$ заспівають нових дум про Остюків бій під Павлівкою» [Яновський 1983: 244]. Але ця пісня, яку проспівали нащадки, «була ніби сліпа, без очей... Пісня була темна, ...здавалася непотрібною $і$ фальшивою» [Яновський 1983: 316 317], не зворушила серця чотирьох побратимів. «За ці хвилини, доки звучала пісня, він зробився на деякий час колишнім Шахаєм. Те, щуо тамувало роки праці на заводі, знову виринуло на поверхню... Пісню він не слухав - вона здавалася йому непотрібною $i$ фальшивою... Швидко буде гудок - знову пращювати, забувши все, крім розпеченого заліза і пекельного вогню» [Яновський 1983: 316317]. «Це покоління, - вважає Р. Харчук, - втрачене не лише тому, що вміє тільки воювати, а й через фальш новонародженого суспільства, якому знову потрібні жертви: ті, щуо вмирають, а не ті, щзо живуть» [Харчук 1999: 51].

Ю. Яновський, Б. Лепкий та Е. М. Ремарк, звертаючись до теми «втраченого покоління», розкривають психологічну кризу вчорашніх фронтовиків, що повернулися з полів Першої світової та громадянської воєн і намагаються віднайти своє місце в чужому, часто ворожому світі, знайти подальший смисл свого існування. Прагнення митців осягнути сенс життя героїв у тогочасній дійсності, показати героїчне минуле й трагічне сучасне характеризує персонажів як особистостей неординарних, які в часи війни мріють самоствердитися, прославитися, а в нефронтовому житті пе- 
реживають крах своїх мрій, непотрібність існування, невідповідність ідеалів і реальності.

\section{БІБЛІОГРАФІЯ}

Дзись 2008 - Дзись Т. В. Творчість Йозефа Рота в українській міжлітературній рецепції : візія Першої світової війни і типологія образів-персонажів (Богдан Лепкий, Мирослав Ірчан, Осип Турянський, Роман Купчинський) : автореф. дис. ... канд. філол. наук : 10.01.05 «Порівняльне літературознавство» / Тарас Васильович Дзись. - Тернопіль, 2008. - 16 с.

Кордонець 2008 - Кордонець О. Повість «Зірка» Б. Лепкого та романи «Повернення» і «Три товариші» Е. М. Ремарка: типологічні паралелі / Олександр Кордонець // Науковий вісник Ужгородського національного університету. - Ужгород, 2008. - Вип. 18. Серія: Філологія. - С. 20-23.

Коссак 1980 - Коссак Е. Экзистенциализм в философии и литературе / Ежжи Коссак ; пер. с польск. - М. : Политиздат, 1980. - 360 с.

Лепкий 1997 - Лепкий Б. Зірка // Лепкий Б. Твори : у 2-х т. / Богдан Лепкий. - К. : Наукова думка, 1997. - Т. 2. - 1997. - С.488-621.

Панченко 1994 - Панченко В. «...І думав я не тільки те, що написав у книжках» (Перечитуючи молодого Юрія Яновського) / Володимир Панченко // Дивослово. - 1994. - № 4. - С. 9-15.

Петраш 1993 - Петраш О. Маловідома повість Богдана Лепкого з повоєнного життя комбатантів Української Галицької Армії «Зірка» / Осип Петраш // Богдан Лепкий - видатний український письменник : збірник статей і матеріалів. Тернопіль, 1993. - С. 122-129.

Ремарк 1986 - Ремарк Е. М. На Західному фронті без змін. Три товариші // Е. М. Ремарк. Твори : у 2-х т. / Еріх Марія Ремарк / пер. $з$ нім., передм. Д. Затонського. К. : Дніпро, 1986. - Т. 1. - 1986. - 573 с.

Харчук 1999 - Харчук Р. Талант і його одержавлення (Юрій Яновський) / Роксолана Харчук // Самототожність письменника. До методології сучасного літературознавства : колективна монографія / відпов. ред. Г. М. Сивокінь. - К. : Українська книга, 1999. - С. 32-54.

Яновський 1983 - Яновський Ю. І. Твори : в 5 т. / Ю. І. Яновський. - Т. 2 : Романи / упоряд., прим. К. П. Волинського, М. Острика ; післям. М. Пархоменка. К. : Дніпро, 1983. -424 с. 